\title{
STUDI DESKRIPTIF KUANTITATIF TINGKAT KEPUASAN KERJA DAN CARA MENGEKSPRESIKAN TINGKAT KEPUASAN KERJA YANG RENDAH PADA KARYAWAN DENGAN MASA KERJA DI ATAS TIGA PULUH TAHUN
}

\author{
Awang Setiawan Wicaksono dan Nyimas Nurhanisah \\ Program Studi Psikologi \\ Universitas Muhammadiyah Gresik \\ Email : awang@gmail.com
}

\begin{abstract}
ABSTRAK
$\mathrm{K}$ epuasan kerja merupakan salah satu faktor yang sangat penting untuk mendapatkan hasil kerja yang optimal. Ketika seorang merasakan kepuasan dalam bekerja tentunya ia akan berupaya semaksimal mungkin dengan segenap kemampuan yang dimilikinya untuk menyelesaikan tugas pekerjaannya. Dalam kenyataannya, di perusahaan, kepuasan kerja secara menyeluruh belum mencapai tingkat maksimal. Masa kerja seseorang akan terpengaruh apabila mendapatkan suatu rangsangan, sehingga orang tersebut mampu mempersepsikannya dengan lebih baik pula. Adanya proses belajar atau pemahaman yang diperoleh seseorang melalui intensitas hubungan yang diperoleh dari masa kerja menjadikan seseorang mampu mempersepsikan kondisi kerjanya lebih baik ataupun lebih buruk. Oleh karena itu tujuan penelitian ini untuk mengetahui tingkat kepuasan kerja karyawan dan bagaimana cara mengekspresikan tingkat kepuasan kerja yang rendah pada karyawan dengan masa kerja di atas tiga puluh tahun. Jumlah subyek penelitian yang digunakan sebanyak 72 karyawan yang bermasa kerja di atas tiga puluh tahun pada jabatan kepala regu (karu), di sini peneliti menggunakan teknik sampling jenuh. Metode pengumpulan data menggunakan kuesioner yang disusun dalam bentuk skala likert, data kedua variabel diolah dengan teknik persentase. Hasil penelitian menunjukkan bahwa terdapat 22 karyawan (30,6\%) yang memiliki tingkat kepuasan kerja rendah, 30 karyawan (41,7\%) memiliki kepuasan kerja sedang, 20 karyawan (27,8\%) memiliki kepuasan kerja tinggi. Faktor-faktor yang mendukung tingkat kepuasan kerja sebagian besar karyawan meliputi tersedianya perlengkapan pegawai yang memadai, kesejahteraan pegawai terjamin dengan adanya layanan kesehatan, dan tersedianya sarana ibadah yang baik. Faktor yang kurang mendukung tingkat kepuasan kerja sebagian karyawan meliputi hasil penelitian kinerja tidak ada umpan balik, penerapan peraturan kurang tegas dan kurang adil, dan belum adanya sistem karir (carrier planning) yang jelas. Sebagian besar cara mengekspresikan tingkat kepuasan rendah cenderung destruktif dan dalam bentuk pindah ke unit kerja lain.
\end{abstract}

Keywords: Tingkat kepuasan kerja, Cara mengekspresikan tingkat kepuasan kerja yang rendah, Masa kerja diatas tiga puluh tahun.

\section{PENDAHULUAN}

\section{A. Latar Belakang}

Bekerja mungkin salah satu cara manusia untuk memenuhi segala kebutuhan yang mereka inginkan. Namun, dalam bekerja seorang manusia tidak hanya memerlukan uang tetapi mereka juga menginginkan adanya peningkatan karir yang bisa menimbulkan kepuasan tersendiri pada diri bawahan sehingga hal itu bisa berpengaruh terhadap peningkatan mutu perusahaan.

Pentingnya karyawan sebagai salah satu faktor produksi karena karyawan mempunyai keinginan yang tidak dimiliki oleh faktor produksi lain, seperti keinginan terjaminnya kepuasan kerja, penghargaan diri dan keinginan untuk mengembangkan diri guna mencapai keberhasilan diri dalam melaksanakan tugas. Jika karyawan merasakan keinginannya mendapat dukungan dari perusahaan untuk kesuksesan karirnya, maka karyawan juga akan merasakan kepuasan kerja yang lebih tinggi. Hal ini juga berlaku sebaliknya. 32
Apabila perusahaan tidak memberikan dukungan untuk kesuksesan karir karyawan, maka karyawan akan merasakan ketidakpuasan. Ketidakpuasan karyawan bisa diwujudkan dalam aksi mogok kerja maupun unjuk rasa.

Pembahasan mengenai kepuasan kerja perlu didahului oleh penegasan bahwa masalah kepuasan kerja bukanlah hal yang sederhana, baik dalam arti konsepnya maupun dalam arti analisisnya, karena kepuasan mempunyai konotasi yang beraneka ragam.

Kepuasan kerja akhir-akhir ini semakin terasa penting artinya dalam lingkup organisasi. Kepuasan kerja mempunyai pengaruh yang cukup besar terhadap produktifitas organisasi baik secara langsung ataupun tidak langsung. Ketidakpuasan merupakan titik awal dari masalah-masalah yang muncul dalam organisasi, seperti kemangkiran, konflik antara manager dan pekerja, turn over, serta banyak masalah lainnya yang menyebabkan 
terganggunya proses pencapaian tujuan organisasi. Dari sisi pekerja, ketidakpuasan dapat menyebabkan menurunnya motivasi, menurunnya moril kerja, menurunnya tampilan kerja baik secara kualitatif maupun secara kuantitatif.

Menurut hasil penelitian Nuzsep Almigo 2004 yang menyimpulkan bahwa terdapat hubungan positif yang signifikan antara kepuasan kerja dengan produktifitas kerja. Hal ini menunjukkan bahwa semakin tinggi kepuasan kerja yang diterima karyawan, semakin tinggi pula produktifitas kerjanya (psikologi.binadarma. ac.id/jurnal/jurnalnuzsep.pdf). Menurut Strauss dan Sayles, kepuasan kerja juga penting untuk aktualisasi diri. Oleh karena itu, kepuasan kerja mempunyai arti penting baik bagi karyawan maupun perusahaan, terutama karena menciptakan keadaan positif di lingkungan kerja perusahaan (Handoko, 1994:196).

Hurlock (1980:320) menjelaskan, pada usia 50 hingga 60 tahun merupakan periode usia madya lanjut dan biasanya terjadi penurunan yang tajam dalam kepuasan terhadap pekerjaan. Pada pria, penurunan tersebut dikarenakan pria saat itu merasa mempunyai kesempatan yang lebih kecil untuk bisa lebih berprestasi walaupun mereka sudah bekerja keras, meningkatkan disiplin kerja, loyalitas dan berbagai daya upayanya. Wanita usia madya, jauh lebih banyak dari pria mengalami kegagalan dalam mencapai puncak prestasi dan kepuasan kerja. Kepuasan kerja merupakan salah satu faktor yang sangat penting untuk mendapatkan hasil kerja yang optimal.

Nampaknya ada suatu sikap yang berbeda pada karyawan pria di bawah umur dua puluh tahun dibandingkan dengan karyawan yang lebih tua. Pada karyawan di bawah umur dua puluh tahun lebih menekankan pentingnya teman sekerja, jam kerja, upah, supervisi, dan kondisi kerja, tetapi kurang menganggap penting faktor lingkungan, pengembangan diri, faedah pekerjaan itu sendiri, perusahaan, dan keamanan kerja. Hal inilah yang mungkin menjadi penyebab mengapa terjadi penurunan kepuasan kerja terhadap pekerjaan mereka. Oleh karena itu dapat dimengerti mengapa karyawan senior merasa lebih puas daripada karyawan yunior (As'ad, 2004:122).

Menurut data Kepegawaian Online PT. Semen Gresik (Persero) Tbk. Tahun 2010, Karyawan yang masa kerja diatas 2 tahun merupakan karyawan atau pegawai tetap karena telah melewati masa kerja 2 tahun tersebut. Perbedaan masa kerja dapat memantau perputaran atau turn over karyawan setiap tahunnya. Disamping itu, dengan adanya sistem masa kerja seperti ini, perusahaan mempunyai landasan yang kuat dalam pemutusan hubungan kerja bagi karyawan yang bekerja dibawah 2 tahun yang dinilai mempunyai kinerja tidak baik. Setelah masa kerja 2 tahun, perusahaan tidak dapat memutuskan hubungan kerja karyawan secara langsung, tetapi mereka menggunakan sistem transfer ke divisi lain terhadap karyawan yang dinilai mempunyai penampilan kerja yang tidak baik pada suatu divisi.

Perbedaan masa kerja yang ada di perusahaan bisa menimbulkan kinerja karyawan menurun. Pada prinsipnya masa kerja seseorang akan terpengaruh apabila mendapatkan suatu rangsangan, sehingga orang tersebut mampu mempersepsikannya dengan lebih baik pula.

\section{B. Batasan Masalah}

Penelitian ini hanya akan membahas dan menggambarkan tingkat kepuasan kerja dan cara mengekspresikan tingkat kepuasan kerja yang rendah pada karyawan dengan masa kerja di atas tiga puluh tahun, dengan memberikan batasan pengertian sebagai berikut:

1. Kepuasan kerja (job satisfaction) adalah merupakan hasil kesimpulan yang didasarkan pada suatu perbandingan mengenai apa yang secara nyata diterima oleh karyawan terhadap pekerjaannya dibandingkan dengan apa yang diharapkan, diinginkan, dan dipikirkannya sebagai hal yang pantas, atau berhak baginya terhadap beberapa aspek yaitu puas terhadap kualitas pekerjaannya (job content), puas terhadap lingkungan kerja, puas terhadap atasan dan puas terhadap kebijakan perusahaan.

2. Cara mengekspresikan tingkat kepuasan kerja yang rendah, dalam penelitian ini ekspresi yang dimaksud pada perilaku, dapat dijelaskan ke dalam empat respons yang berbeda dari satu sama lain.

3. Masa kerja adalah hitungan lamanya pegawai dalam bekerja di perusahaan, dalam penelitian ini subyek yang akan diteliti adalah subyek yang memiliki masa kerja diatas tiga puluh tahun.

\section{Rumusan Masalah}

Berdasarkan latar belakang masalah diatas, maka dalam penelitian ini dapat dirumuskan suatu 
masalah sebagai berikut :

1. Bagaimana tingkat kepuasan kerja karyawan?

2. Faktor-faktor apakah yang mempengaruhi tingkat kepuasan kerja karyawan?

3. Bagaimana cara mengekspresikan tingkat kepuasan kerja yang rendah pada karyawan dengan masa kerja di atas tiga puluh tahun?

\section{LANDASAN TEORI}

\section{Definisi Kepuasan Kerja}

Kepuasan kerja (job satisfaction) dapat didefinisikan sebagai suatu perasaan positif tentang pekerjaan seseorang yang merupakan hasil dari sebuah evaluasi karakteristiknya. Seseorang dengan tingkat kepuasan kerja yang tinggi memiliki perasaan-perasaan positif tentang pekerjaan tersebut, sementara seseorang yang tidak puas memiliki perasaan-perasaan negatif tentang pekerjaan tersebut (Robbins, 2008:99).

Gibson (2002:150) mengatakan kepuasan kerja adalah suatu sikap yang dipunyai pekerja mengenai pekerjaannya. Wexley dan Yuki (2005:129) mengatakan yang disebut kepuasan kerja adalah cara seorang pekerja merasakan pekerjaannya.

Sedangkan Tiffin (1956) berpendapat bahwa kepuasan kerja berhubungan erat dengan sikap dari karyawan terhadap pekerjaannya sendiri, situasi kerja dan kerjasama antara pimpinan dengan sesama karyawan. Kemudian Blum (1956) mengemukakan bahwa kepuasan kerja merupakan sikap umum yang merupakan hasil dari beberapa sikap khusus terhadap faktor-faktor pekerjaan, penyesuaian diri dan hubungan sosial individual di luar kerja (As'ad, 2004:104).

Dari pendapat diatas, dapat disimpulkan bahwa kepuasan kerja adalah merupakan hasil kesimpulan yang didasarkan pada suatu perbandingan mengenai apa yang secara nyata diterima oleh karyawan terhadap pekerjaannya dibandingkan dengan apa yang diharapkan, diinginkan, dan dipikirkannya sebagai hal yang pantas, atau berhak baginya terhadap beberapa aspek.

\section{Faktor-faktor yang Mempengaruhi Kepuasan Kerja.}

Terdapat dua kelompok faktor yang mempengaruhi kepuasan kerja. Faktor pertama yaitu faktor intrinsik adalah faktor yang berasal dari dalam diri dan dibawa oleh setiap karyawan sejak mulai bekerja di tempat pekerjaannya, yang dalam penelitian ini adalah perusahaan. Faktor ekstrinsik menyangkut hal-hal yang berasal dari luar diri karyawan, antara lain kondisi fisik lingkungan kerja, interaksinya dengan karyawan lain, sistem penggajian dan sebagainya.

Pada individu ada dua prediktor penting terhadap kepuasan kerja yaitu status dan senioritas. Status kerja yang rendah dan pekerjaan yang rutin akan banyak kemungkinan mendorong karyawan untuk mencari pekerjaan lain, hal ini berarti dua faktor tersebut dapat menyebabkan ketidakpuasan kerja dan karyawan yang memiliki ketertarikan dan tantangan kerja akan lebih merasa puas dengan hasil kerjanya apabila mereka dapat menyelesaikan dengan maksimal.

Wexley dan Yuki (1977) berpendapat bahwa pekerjaan yang terbaik bagi penelitianpenelitian tentang kepuasan kerja adalah dengan memperhatikan baik faktor pekerjaan maupun faktor individunya. Faktor-faktor yang mempengaruhi kepuasan kerja yaitu gaji, kondisi kerja, mutu pengawasan, teman sekerja, jenis pekerjaan, keamanan kerja dan kesempatan untuk maju serta faktor individu yang berpengaruh adalah kebutuhan-kebutuhan yang dimilikinya, nilai-nilai yang dianut dan sifat-sifat kepribadian (Wexley \& Yuki, 2005:35).

Sedangkan Faktor-faktor yang memberikan kepuasan kerja menurut Blum (1956) sebagai berikut :

a. Faktor individual, meliputi umur, kesehatan, watak dan harapan.

b. Faktor sosial, meliputi hubungan kekeluargaan, pandangan masyarakat, kesempatan berkreasi, kegiatan perserikatan pekerja, kebebasan berpolitik, dan hubungan kemasyarakatan.

c. Faktor utama dalam pekerjaan, meliputi upah, pengawasan, ketentraman kerja, dan kesempatan untuk maju. Selain itu juga penghargaan terhadap kecakapan, hubungan sosial di dalam pekerjaan, ketepatan dalam menyelesaikan konflik antar manusia, perasaan diperlakukan adil baik yang menyangkut pribadi maupun tugas (As'ad, 2004:114).

Dikarenakan setiap individu akan memiliki tingkat kepuasan yang berbeda-beda sesuai dengan sistem nilai yang berlaku pada dirinya. Ini disebabkan adanya perbedaan persepsi pada masing-masing individu. Semakin banyak aspek dalam pekerjaan yang sesuai dengan keinginan individu tersebut maka semakin tinggi tingkat 
kepuasan yang dirasakannya.

\section{Dampak Kepuasan dan Ketidakpuasan Kerja}

Dampak perilaku dari kepuasan dan ketidakpuasan kerja telah banyak diteliti dan dikaji. Ketidakpuasan kerja dapat berdampak pada produktivitas, ketidakhadiran dan keluarnya pegawai serta dampaknya terhadap kesehatan.

Lawler dan Porter menunjukkan jika produktivitas yang tinggi akan menyebabkan peningkatan dari kepuasan kerja hanya jika tenaga kerja mempersepsikan bahwa ganjaran instrinsik dan ganjaran ekstrinsik yang diterima keduaduanya adil dan wajar serta diasosiasikan dengan unjuk kerja yang unggul, jika tenaga kerja tidak mempersepsikan ganjaran intrinsik dan ekstrinsik berasosiasi dengan unjuk kerja, maka kenaikan dalam unjuk kerja tidak akan berkorelasi dengan kenaikan kepuasan kerja.

Sdangkan Porter \& Steers berkesimpulan bahwa ketidakhadiran dan berhenti bekerja merupakan jenis jawaban yang secara kualitatif berbeda. Ketidakhadiran lebih bersifat spontan dan kurang mencerminkan ketidakpuasan kerja. Perilaku ini karena akan mempunyai akibat-akibat ekonomis yang besar, maka lebih besar kemungkinannya berhubungan dengan ketidakpuasan kerja.

Meskipun jelas bahwa kepuasan kerja berhubungan dengan kesehatan, hubungan kausalnya masih tidak jelas. Diduga bahwa kepuasan kerja menunjang tingkat dari fungsi fisik mental dan kepuasan sendiri merupakan tanda dari kesehatan. Tingkat dari kepuasan kerja dan kesehatan mungkin saling mengukuhkan sehingga peningkatan dari yang satu dapat meningkatkan yang lain dan sebaliknya penurunan yang satu mempunyai akibat yang negatif juga pada yang lain. (Munandar, 2006: 364-367).

\section{Cara Mengekspresikan Tingkat Kepuasan Kerja yang Rendah}

Vroom (1964) menemukan hubungan yang konsisten antara ketidakpuasan dengan penarikan diri dalam bentuk perpindahan dan absensi. Para pekerja yang tidak puas dengan pekerjaannya lebih mungkin menyingkir dari kerja atau pindah dibanding para pekerja yang puas. Bentuk lain dari perilaku penarikan adalah minumminuman keras dan minum obat bius, kurang mendapatkan perhatian dalam literatur penelitian, justru mungkin sekali mereka mengaitkan dengan ketidakpuasan kerja dalam batas-batas tertentu (Wexley \& Yuki, 2005:156).

Frustasi yang menyertai ketidakpuasan kerja dapat mengarah pada perilaku agresif daripada penarikan diri. Tindakan agresif dapat berbentuk sabotase, sengaja melakukan kesalahan, serta kegiatan-kegiatan serikat buruh yang militan seperti pemogokan yang tidak bertanggung jawab, pelambatan kerja, serta protes yang berlebihan. Jadi banyak terjadi pertengkaran dan permusuhan di antara pekerja ketika mereka sangat frustasi (Wexley \& Yuki, 2005:157).

Menurut Strauss dan Sayles, karyawan yang tidak memperoleh kepuasan kerja tidak akan pernah mencapai kematangan psikologis, dan pada gilirannya akan menjadi frustasi. Karyawan seperti ini akan sering melamun, mempunyai semangat kerja rendah, cepat lelah dan bosan, emosinya tidak stabil, sering absen dan melakukan kesibukan yang tidak ada hubungannya dengan pekerjaan yang harus dilakukan (Handoko, 1994:196).

Kepuasan kerja yang lebih rendah biasanya akan mengakibatkan perputaran karyawan lebih tinggi. Mereka lebih mudah meninggalkan perusahaan dan mencari kesempatan di perusahan lain. Hubungan serupa berlaku juga untuk absensi. Para karyawan yang kurang mendapatkan kepuasan kerja cenderung lebih sering absen. Mereka sering tidak merencanakan absen, tetapi bila ada berbagai alasan untuk absen, mereka lebih mudah menggunakan alasan-alasan tersebut (Handoko, 1994:197).

Menurut Robbins (2008:115) empat respons konsekuensi dari ketidakpuasan yang berbeda dari satu sama lain terletak pada dua dimensi: konstruktif/destruktif dan aktif/pasif yang dideskripsikan sebagai berikut:

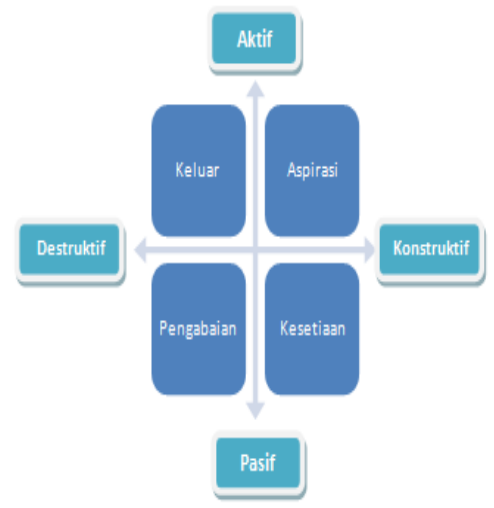

Respons Terhadap Ketidakpuasan Kerja Sumber : Robbins, (2008:115) 


\section{Pengertian Masa Kerja}

Sondang (2000) mengatakan bahwa masa kerja merupakan keseluruhan pelajaran yang dipetik oleh seseorang dari peristiwa-peristiwa yang dilalui dalam perjalanan hidupnya. Sedangkan Susilo Martoyo berpendapat bahwa masa kerja atau pengalaman kerja adalah mereka yang dipandang lebih mampu dalam melaksanakan tugas-tugasnya yang nantinya akan diberikan disamping kemampuan intelegensinya yang juga menjadi dasar pertimbangan selanjutnya.

Pengalaman tidak selalu menjamin prestasi yang lebih baik. Sering terjadi seorang yang belum dapat dikatakan berpengalaman ternyata mampu berprestasi lebih baik. Di samping itu, antara pengalaman dan loyalitas sangat erat hubungannya. Untuk itulah, syarat pengalaman tetap dicantumkan oleh sebagian perusahaan

\section{Tahap Perkembangan Karir}

Perjalanan karir setiap orang melalui serangkaian tahap tertentu. Dessler (1997:547) menjelaskan tahapan karir sebagai berikut:

a. Tahap Pertumbuhan (usia $0-14$ tahun); periode ketika seseorang mengembangkan citra pribadi dengan mengidentifikasikan dirinya dan berinteraksi dengan orang lain.

b. Tahap Explorasi (usia 15 - 24 tahun); periode seseorang berusaha menggali berbagai alternatif secara serius, dengan upaya membandingbandingkan alternatif tersebut dengan hal-hal yang telah dipelajarinya.

c. Tahap Pemantapan (usia $24-44$ tahun); inti kehidupan kerja setiap orang pada umumnya. Adakalanya pada periode ini diperoleh keahlian yang sesuai dan orang yang bersangkutan terlibat dalam aktivitas-aktivitas yang membantunya untuk memperoleh tempat yang tetap.

d. Tahap Pemeliharaan (usia $45-65$ tahun); tahap seseorang telah menciptakan suatu tempat dalam dunia kerja dan semua upaya umumnya diarahkan untuk mengamankan tempat tersebut.

e. Tahap Kemunduran (usia lebih dari 65 tahun); periode perlambatan saat usia pensiun mendekat pada tahap ini banyak orang menghadapi prospek untuk menerima keadaan menurunnya level kekuasaan dan tanggung jawab. Pada saat seperti ini, mereka harus belajar menerima dan mengembangkan peranan baru sebagai mentor dan orang kepercayaan bagi karyawan yang lebih muda.

Simamora (2004:416) menjelaskan, riset terakhir menunjukkan bahwa karir melalui suatu rangkaian fase/tahap yang relatif dapat diprediksi, dimulai dengan eksplorasi dan investigasi awal terhadap kesempatan karir dan diakhiri dengan pensiun. Perencanaan karir mestilah mengingat isu dan tugas yang berbeda yang dihadapi individu di setiap tahap tersebut. Karir dan model taraf hidup sangatlah berkaitan karena keduanya berhubungan dengan usia dan norma kultural. Keduanya mengungkapkan pola pertumbuhan yang berulang, atau mengasah kecakapan baru dan menantang tatkala seseorang memasuki sebuah tahap stabilisasi, atau memperagakan kinerja yang sangat produktif selama suatu tahap dan transisi, atau membuat perubahan dari tuntutan tahap sekarang ke tuntutan yang diantisipasi pada tahap berikutnya di berbagai tahap kehidupan dan karirnya.

\begin{tabular}{|c|c|c|c|c|}
\hline $\begin{array}{c}\text { Tingkat } \\
\text { Karir }\end{array}$ & $\begin{array}{l}\text { Karir } \\
\text { Awal }\end{array}$ & $\begin{array}{c}\text { Karir } \\
\text { Menengah }\end{array}$ & $\begin{array}{l}\text { Karir } \\
\text { Akhir }\end{array}$ & $\begin{array}{l}\text { Akhir } \\
\text { Karir }\end{array}$ \\
\hline Kelompok Usia & 20 tahun & 30-40 tahun & 50 tahun & $60-70$ tahun \\
\hline Kebutuhan: & $\begin{array}{l}\text { M e n g e n a li } \\
m \text { i n a t }, \\
\text { mengeksplorasi } \\
\text { b e b e } r \text { a p a } \\
\text { pekerjaan }\end{array}$ & $\begin{array}{l}\text { Mendahulukan } \\
\text { karier; } \\
\text { gaya hidup } \\
\text { mungkin } \\
\text { membatasi } \\
\text { opsi-opsi, } \\
\text { pertumbuhan, } \\
\text { dan kontribusi }\end{array}$ & $\begin{array}{l}\text { Memperbarui } \\
\text { keterampilan; } \\
\text { m e n e t a p, } \\
\text { pemimpin, } \\
\text { opini-opini } \\
\text { dihargai }\end{array}$ & $\begin{array}{l}\text { Merencanakan } \\
\text { pensiun, memeriksa } \\
\text { minat-minat yang } \\
\text { tidak berhubungan } \\
\text { dengan kerja. }\end{array}$ \\
\hline Kekhawatiran: & $\begin{array}{l}\text { Penghargaan } \\
\text { eks terna } 1, \\
\text { mendapatkan } \\
\text { lebih banyak } \\
\text { kapabilitas }\end{array}$ & $\begin{array}{l}\text { Nilai-nilai } \\
\text { kontribusi, } \\
\text { integritas, } \\
\text { kesejahteraan. }\end{array}$ & $\begin{array}{l}\text { Bimbingan, } \\
\text { pelepasan, } \\
\text { kelanjutan } \\
\text { organisasi }\end{array}$ & $\begin{array}{l}\text { Pensiun, pekerjaan } \\
\text { paruh waktu }\end{array}$ \\
\hline
\end{tabular}

Periode Karir yang Umum

Sumber : Mathis RL \& Jackson JH, (2006:346) 


\section{Pengertian Manajer Lini}

Manajemen linipertama (first-linemanagement), dikenal pula dengan istilah manajemen operasional, merupakan manajemen tingkatan paling rendah yang bertugas memimpin dan mengawasi karyawan non-manajerial yang terlibat dalam proses produksi. Para manajer ini sering disebut dengan penyelia (supervisors), manajer shift, manajer area, manajer kantor, manajer departemen, atau mandor (foremen) yang pada umumnya memiliki keterampilan teknis (technical skill) yaitu kemampuan untuk menjalankan suatu pekerjaan tertentu, misalnya menggunakan komputer, memperbaiki mesin, akuntansi dan lain-lain.

Pada tingkatan ini, para manajer akan banyak melaksanakan fungsi manajemen operatif yaitu lebih mencakup kegiatan memotivasi, supervisi, dan komunikasi dengan para karyawan untuk mengarahkan mereka mencapai hasil-hasil secara efektif (Handoko, 2008:19).

\section{Kerangka Konseptual}

Kerangka konseptual dalam penelitian ini dapat digambarkan sebagai berikut:

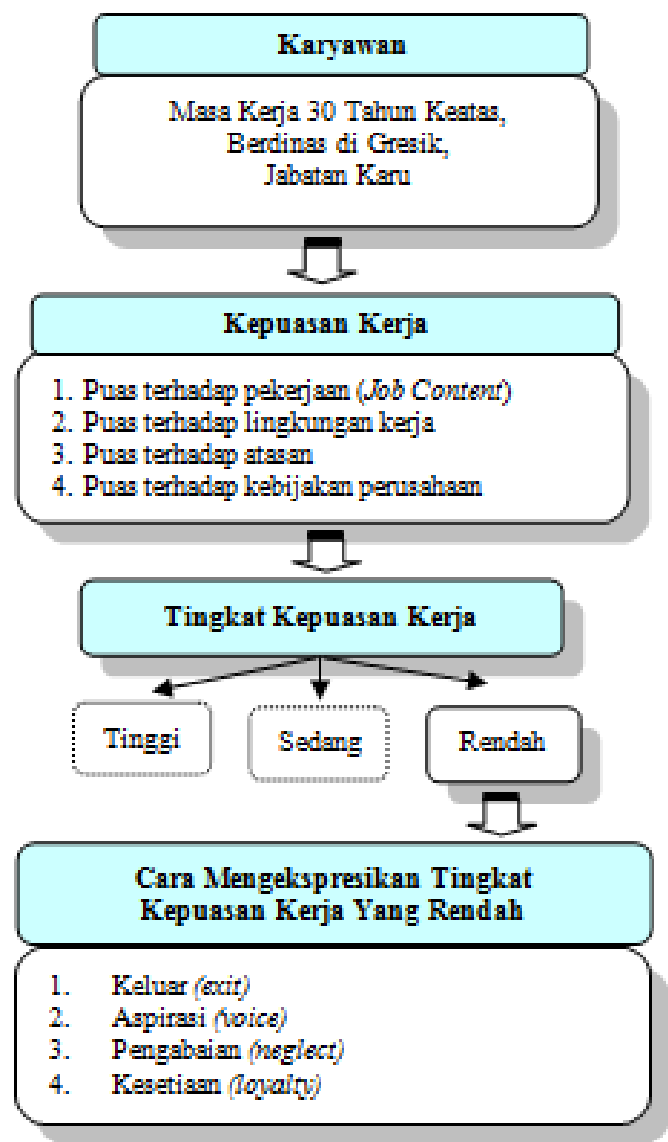

Kerangka Konseptual Penelitian

\section{METODE PENELITIAN}

\section{A. Tipe Penelitian}

Penelitian ini menggunakan metode kuantitatif deskriptif. Metode kuantitatif deskriptif adalah suatu metode dalam meneliti status sekelompok manusia, suatu objek, suatu set kondisi, suatu sistem pemikiran, ataupun suatu kelas peristiwa pada masa sekarang dengan menggunakan metode penyebaran kuesioner untuk memperoleh data atau informasi dari responden untuk menyusun deskripsi, gambaran atau lukisan secara sistematis, faktual dan akurat mengenai fakta-fakta, sifat-sifat serta hubungan antar fenomena yang diselidiki (Nazir, 2009:54).

\section{B. Definisi Operasional}

Dalam penelitian ini, kepuasan kerja (job satisfaction) didefinisikan sebagai hasil kesimpulan yang didasarkan pada suatu perbandingan mengenai sesuatu yang secara nyata diterima oleh karyawan terhadap pekerjaannya dibandingkan dengan yang diharapkan, diinginkan, dan dipikirkannya sebagai hal yang pantas, atau berhak baginya. Indikator/ sub indikator dari kepuasan kerja adalah sebagai berikut :

1. Puas terhadap kualitas pekerjaan (job content)

a. Persepsi terhadap pekerjaan

b. Kebebasan \& otonomi

2. Puas terhadap lingkungan kerja yang mendukung
a. Fisik
b. Sosial

3. Puas terhadap atasan

a. Mutu pengawasan

4. Puas terhadap kebijakan perusahaan dalam hal pengelolaan SDM
a. Sistem benefit
b. Sistem penilaian kinerja
c. Sistem peraturan kepegawaian
d. Sistem karir (carrier planning)
e. Sistem pelatihan dan pengembangan SDM

Sedangkan Cara Mengekspresikan Tingkat Kepuasan Kerja yang Rendah didefinisikan menurut Robbins (2008:115) dengan menjelaskan empat respons konsekuensi dari ketidakpuasan yang berbeda satu sama lain terletak pada dua dimensi, yaitu konstruktif dan destruktif yang didefinisikan sesuai indikator sebagai berikut :

1. Respons konstruktif :

a. Aspirasi (voice) : Secara aktif dan konstruktif berusaha memperbaiki kondisitermasuk 
menyarankan perbaikan, mendiskusikan masalah dengan atasan, dan beberapa bentuk aktivitas serikat pekerja. Sub indikator dari ekspresi aspirasi adalah sebagai berikut :

1. Saran kepada atasan, pihak terkait \& serikat pegawai

2. Diskusi dengan atasan, pihak terkait \& serikat pegawai

b. Kesetiaan (loyalty) : Secara pasif tetap optimis menunggumembaiknyakondisi, termasuk membela organisasi ketika menghadapi kecaman eksternal dan mempercayai organisasi dan manajemennya untuk "melakukan hal yang benar". Sub indikator dari ekspresi kesetiaan adalah sebagai berikut :

1. Menunggu kondisi menjadi baik

2. Membela organisasi

3. Mempercayai organisasi \& manajemen

2. Respons destruktif :

a. Keluar (exit) : Perilaku aktif yang ditujukan untuk meninggalkan organisasi, termasuk mencari posisi baru dan mengundurkan diri. Sub indikator dari ekspresi keluar adalah sebagai berikut :

1. Keluar perusahaan

2. Pindah unit kerja

b. Pengabaian (neglect): Secara pasif membiarkan kondisi menjadi lebih buruk, termasuk ketidakhadiran atau keterlambatan yang terus menerus, kurangnya usaha, dan meningkatnya angka kesalahan. Sub indikator dari ekspresi pengabaian adalah sebagai berikut :

1. Membiarkan kondisi menjadi lebih buruk

2. Tidak masuk kerja

3. Terlambat

4. Kurang usaha

5. Meningkatnya angka kesalahan

\section{Populasi dan Sampel}

Populasi penelitian adalah karyawan di sebuah perusahaan di Kota Gresik yang berdinas di Gresik, dengan masa kerja di atas tiga puluh tahun pada jabatan kepala regu (karu), populasi berjumlah 72 orang.

Sedangkan teknik sampling yang digunakan dalam penelitian ini menggunakan sampling jenuh. Hal ini dilakukan karena jumlah populasi relatif kecil, dan keinginan peneliti membuat generalisasi dengan kesalahan yang sangat kecil.

\section{Teknik Pengumpulan Data}

Teknik pengumpulan data yang digunakan dalam penelitian ini dengan menggunakan skala likert untuk mengumpulkan data tingkat kepuasan kerja dan cara mengekspresikan tingkat kepuasan yang rendah pada karyawan, sedangkan untuk penentuan masa kerja berdasarkan dokumen resmi perusahaan.

\section{Teknik Analisis Data}

Data yang didapatkan akan dianalisis dengan persentase menggunakan bantuan program komputer SPSS 17. Analisis persentase ini dipilih karena sesuai dengan tujuan penelitian yaitu mendeskripsikan tentang tingkat kepuasan kerja, faktor-faktor yang mempengaruhi tingkat kepuasan kerja sebagian besar karyawan dan cara mengekspresikan tingkat kepuasan kerja yang rendah pada karyawan dengan masa kerja di atas tiga puluh tahun. Teknik persentase ini dianggap sudah representatif karena hasil analisis data yang diperoleh sudah dapat disimpulkan dan dapat dijadikan acuan untuk mengetahui tercapainya tujuan penelitian.

\section{HASIL PENELITIAN}

Dalam menganalisis data adalah dengan menggunakan bantuan program SPSS 17, dengan distribusi frekuensi dan tabulasi silang, yaitu untuk memaparkan tingkat kepuasan kerja, faktor-faktor yang mendukung tingkat kepuasan kerja dan ekspresi tingkat kepuasan kerja yang rendah, yang terdiri dari ekspresi secara konstruktif dan secara destruktif.

1. Kategori tingkat kepuasan kerja

Tabel 1. Tingkat Kepuasan Kerja

\begin{tabular}{|c|c|c|}
\hline $\begin{array}{c}\text { Tingkat Kepuasan } \\
\text { Kerja }\end{array}$ & $\begin{array}{l}\text { Frekuensi } \\
\text { Subyek }\end{array}$ & $\%$ \\
\hline Rendah & 22 & 30,6 \\
\hline Sedang & 30 & 41,7 \\
\hline Tinggi & 20 & 27,8 \\
\hline Jumlah & 72 & 100 \\
\hline
\end{tabular}

Tabel 1 menunjukkan bahwa responden yang tingkat kepuasan kerjanya rendah $30,6 \%$ dan tingkat kepuasan kerjanya tinggi $27,8 \%$ serta mayoritas responden memiliki tingkat kepuasan kerja sedang $41,7 \%$.

\section{Faktor-faktor tingkat kepuasan kerja}


Tabel 2. Faktor yang Mendukung Tingkat Kepuasan Kerja Sebagian Besar Karyawan

\begin{tabular}{|c|c|c|c|}
\hline \multirow[t]{2}{*}{ No. } & \multirow[t]{2}{*}{ Pernyataan } & \multicolumn{2}{|c|}{ Persentase } \\
\hline & & $4(\mathrm{~S})$ & $5(\mathrm{SS})$ \\
\hline 1. & $\begin{array}{l}\text { Saya mendapatkan } \\
\text { perlengkapan pegawai } \\
\text { dengan memadai, antara } \\
\text { lain: seragam, sepatu, dari } \\
\text { perusahaan }\end{array}$ & 55,6 & 41,7 \\
\hline 2. & $\begin{array}{l}\text { Saya mendapatkan sarana } \\
\text { beribadah yang baik } \\
\text { yang telah di sediakan } \\
\text { perusahaan untuk } \\
\text { pegawai }\end{array}$ & 75,0 & 18,1 \\
\hline 3. & $\begin{array}{l}\text { Saya merasa perusahaan } \\
\text { telah menyediakan } \\
\text { fasilitas olahraga dengan } \\
\text { baik }\end{array}$ & 73,6 & 18,1 \\
\hline 4. & $\begin{array}{l}\text { Saya mendapatkan } \\
\text { layanan kesehatan dari } \\
\text { perusahaan dengan } \\
\text { memadai }\end{array}$ & 75,0 & 22,2 \\
\hline 5. & $\begin{array}{l}\text { Saya bangga pada } \\
\text { perusahaan yang telah } \\
\text { menyediakan sarana } \\
\text { pelayanan kesehatan } \\
\text { dengan baik (Rumah } \\
\text { Sakit, Poliklinik, Apotek) }\end{array}$ & 59,7 & 25,0 \\
\hline
\end{tabular}

Dari tabel 2 terdapat tiga item pernyataan yang mendapat respon tinggi yaitu, saya mendapatkan perlengkapan pegawai dengan memadai, antara lain seragam, sepatu, dari perusahaan $(97,3 \%)$, saya mendapatkan layanan kesehatan dari perusahaan dengan memadai $(97,2 \%)$, dan saya mendapatkan sarana beribadah yang baik yang telah disediakan perusahaan untuk pegawai $(93,1 \%)$, Perlengkapan pegawai yang diterima karyawan berupa seragam yang diberikan setahun sekali dan sepatu setiap dua tahun sekali membuat karyawan merasa nyaman dalam bekerja, sarana ibadah yang di sediakan perusahaan bisa membantu karyawan meningkatkan kecerdasan spiritual, layanan kesehatan yang memadai membuat karyawan dan keluarganya mudah mendapatkan layanan kesehatan yang dibutuhkan. Fasilitas atau sarana tersebut bisa mendukung kepuasan kerja sebagian besar karyawan.

Tabel 3. Faktor yang Kurang Mendukung Tingkat Kepuasan Kerja Sebagian Karyawan (Favorable)

\begin{tabular}{|c|l|c|c|}
\hline \multirow{2}{*}{ No. } & \multicolumn{1}{|c|}{ Pernyataan } & \multicolumn{2}{c|}{ Persentase } \\
\cline { 3 - 4 } & & $2(\mathrm{TS})$ & 1 (STS) \\
\hline 1. & $\begin{array}{l}\text { Saya mengetahui } \\
\text { / diberitahu hasil } \\
\text { penilaian kinerja saya }\end{array}$ & 62,3 & 8,3 \\
\hline 2. & $\begin{array}{l}\text { Saya rasa sistem } \\
\text { penilaian kinerja yang } \\
\text { ada saat ini dapat } \\
\text { mengukur kinerja } \\
\text { dengan adil }\end{array}$ & 36,1 & 4,2 \\
\hline 3. & $\begin{array}{l}\text { Saya merasa } \\
\text { perusahaan telah } \\
\text { memberikan } \\
\text { kesempatan yang adil } \\
\text { bagi pegawai untuk } \\
\text { berkarir }\end{array}$ & 18,1 & 22,2 \\
\hline
\end{tabular}

Tabel 4. Faktor yang Kurang Mendukung Tingkat Kepuasan Kerja Sebagian Karyawan (Unfavorable)

\begin{tabular}{|c|l|c|c|}
\hline No. & \multicolumn{1}{|c|}{ Pernyataan } & \multicolumn{2}{c|}{ Persentase } \\
\cline { 3 - 4 } 1. & $\begin{array}{l}\text { Saya kecewa atas ketidak } \\
\text { adilan perusahaan } \\
\text { dalam menangani setiap } \\
\text { permasalahan pegawai }\end{array}$ & 36,1 & 6,9 \\
\hline 2. & $\begin{array}{l}\text { Saya kecewa terhadap } \\
\text { tindakan perusahaan yang } \\
\text { kurang tegas menindak } \\
\text { pegawai yang melanggar } \\
\text { peraturan }\end{array}$ & 48,6 & 5,6 \\
\hline 3. & $\begin{array}{l}\text { Saya kecewa karena } \\
\text { perusahaan belum } \\
\text { menerapkan sistem } \\
\text { karir yang tepat dalam } \\
\text { pengembangan karir } \\
\text { pegawai }\end{array}$ & 23,6 & 30,6 \\
\hline
\end{tabular}

Dari tabel 3 dan 4 diatas, terdapat tiga item pernyataan favorable yang mendapat respon tinggi yaitu, saya mengetahui / diberitahu hasil penilaian kinerja saya $(70,6 \%)$, saya rasa sistem penilaian kinerja yang ada saat ini dapat mengukur kinerja dengan adil (40,3\%), dan saya merasa Perusahaan telah memberikan kesempatan yang adil bagi Pegawai untuk berkarir (40,3\%). Pada pernyataan unfavorable terdapat tiga item pernyataan yang sesuai dengan pernyataan favorable yaitu, saya kecewa karena perusahaan belum menerapkan sistem karir yang tepat dalam pengembangan karir pegawai $(54,2 \%)$, saya kecewa terhadap tindakan Perusahaan yang kurang tegas menindak pegawai yang melanggar peraturan $(54,2 \%)$, dan saya 
kecewa atas ketidak adilan Perusahaan dalam menangani setiap permasalahan Pegawai (43\%).

Perusahaan belum transparan dalam memberitahu hasil penilaian kinerja yang dirasakan kurang adil bagi karyawan, kekurangtegasan dalam menindak pegawai yang melanggar peraturan serta ketidakadilan dalam menangani permasalahan karyawan maupun perusahaan yang belum menerapkan sistem karir yang tepat merupakan faktor yang menyebabkan tingkat kepuasan rendah pada karyawan.

\section{Ekspresi Tingkat Kepuasan Kerja yang Rendah}

Tabel 5. Ekspresi Tingkat Kepuasan Kerja yang Rendah Cenderung Destruktif

\begin{tabular}{|l|c|c|}
\hline $\begin{array}{c}\text { Ekspresi Tingkat Kepuasan } \\
\text { Kerja Rendah Cenderung } \\
\text { Destruktif }\end{array}$ & $\begin{array}{c}\text { Frekuensi } \\
\text { Subyek }\end{array}$ & $\%$ \\
\hline Keluar (exit) & 16 & 72,7 \\
Pengabaian (neglect) & 6 & 27,3 \\
\hline \multicolumn{1}{|c|}{ Jumlah } & 22 & 100 \\
\hline
\end{tabular}

Tabel 6. Bentuk Perilaku dari Ekspresi Tingkat Kepuasan Kerja yang Rendah Cenderung Destruktif

\begin{tabular}{|c|l|c|c|}
\hline \multirow{2}{*}{ No. } & \multicolumn{1}{|c|}{ Pernyataan } & \multicolumn{2}{|c|}{ Persentase } \\
\cline { 3 - 4 } & & $4(\mathrm{~S})$ & $5(\mathrm{SS})$ \\
\hline 1. & $\begin{array}{l}\text { Saya pindah ke unit } \\
\text { kerja lain jika belum ada } \\
\text { perubahan seperti yang } \\
\text { saya harapkan }\end{array}$ & 13,6 & 63,6 \\
\hline 2. & $\begin{array}{l}\text { Saya bekerja sesuai } \\
\text { kemampuan saya tanpa } \\
\text { peduli target perusahan }\end{array}$ & 18,2 & 50,0 \\
\hline
\end{tabular}

Tabel 5 dan 6 menunjukkan bahwa dari 22 responden yang menggambarkan ekspresi tingkat kepuasan kerja rendah cenderung keluar (exit) $72,7 \%$ dalam bentuk perilaku saya pindah ke unit kerja lain jika belum ada perubahan seperti yang saya harapkan $(77,2 \%)$ dan cenderung pengabaian (neglect) $27,3 \%$ dalam bentuk perilaku saya bekerja sesuai kemampuan saya tanpa peduli target perusahan $(68,2 \%)$.

Berdasarkan data angket terbuka dan wawancara kepada responden, karyawan cenderung memilih pindah ke unit kerja lain yang dirasa lebih sesuai untuk dirinya dan beberapa karyawan mengabaikan dengan berbagai alasan untuk tidak melaksanakan pekerjaannya dengan baik karena karyawan tersebut merasa dirinya telah berbuat banyak untuk perusahaan sehingga telah tiba waktunya bekerja santai, datang dan pulang tepat waktu serta seringkali mengatakan kepada karyawan yang lebih muda untuk bekerja lebih giat, bahkan tidak jarang pula meminta atau mengalihkan sebagian tanggung jawab yang seharusnya menjadi tanggung jawab karyawan tersebut.

Berdasarkan wawancara dengan bagian pengelolaan Sumber Daya Manusia, memang terdapat kecenderungan sebagian karyawan dengan masa kerja 30 tahun keatas yang pindah ke unit kerja lain, namun data tidak menyebutkan secara pasti tentang alasan karyawan tersebut pindah ke unit kerja lain. Hal ini dikarenakan sistem perpindahan karyawan dari unit kerja satu ke unit kerja lain bisa berdasarkan permintaan dari unit kerja tertentu dan hal itu tidak disertai alasan secara mendetail.

Tabel 7. Ekspresi Tingkat Kepuasan Kerja yang Rendah Cenderung Konstruktif

\begin{tabular}{|c|c|c|}
\hline $\begin{array}{c}\text { Ekspresi Tingkat Kepuasan } \\
\text { Kerja Rendah Cenderung } \\
\text { Konstruktif }\end{array}$ & $\begin{array}{c}\text { Frekuensi } \\
\text { Subyek }\end{array}$ & $\%$ \\
\hline $\begin{array}{l}\text { Aspirasi } \\
\text { Kesetiaan }\end{array}$ & $\begin{array}{l}11 \\
11\end{array}$ & $\begin{array}{l}50 \\
50\end{array}$ \\
\hline Jumlah & 22 & 100 \\
\hline
\end{tabular}

Tabel 8. Bentuk Perilaku dari Ekspresi Tingkat Kepuasan Kerja Rendah Cenderung Konstruktif

\begin{tabular}{|c|l|c|c|}
\hline \multirow{2}{*}{ No. } & \multicolumn{1}{|c|}{ Pernyataan } & \multicolumn{2}{c|}{ Persentase } \\
\cline { 3 - 4 } 1. & $\begin{array}{l}\text { Saya bersedia berdiskusi dengan } \\
\text { pihak terkait untuk membuat } \\
\text { suatu perubahan yang dibutuhkan }\end{array}$ & 59,1 & 4,5 \\
\hline 2 & $\begin{array}{l}\text { Saya percaya manajemen } \\
\text { melakukan hal terbaik dalam } \\
\text { membuat perubahan }\end{array}$ & 0 & 95,5 \\
\hline
\end{tabular}

Tabel 7 dan 8 menunjukkan bahwa dari 22 responden yang menggambarkan ekspresi tingkat kepuasan kerja yang rendah cenderung memberikan aspirasi $50 \%$ dalam bentuk saya bersedia berdiskusi dengan pihak terkait untuk membuat suatu perubahan yang dibutuhkan $(63,6 \%)$, dan cenderung kesetiaan 50\% dalam bentuk saya percaya manajemen melakukan hal terbaik dalam membuat perubahan (95,5\%).

Kepuasan kerja mempunyai arti penting baik bagi karyawan maupun perusahaan, terutama karena menciptakan keadaan positif di lingkungan kerja perusahaan. Telah umum dimaklumi bahwa kehidupan berkarya digunakan oleh manusia tidak hanya untuk memuaskan kebutuhan material 
saja, akan tetapi juga untuk memenuhi berbagai kebutuhan lainnya seperti yang bersifat mental, psikologikal, sosial dan spiritual. Siagian (2007:299) menjelaskan, dilihat dari sudut pandangan tersebut, besar kecilnya organisasi turut berpengaruh pada kepuasan kerja.
Berdasarkan hasil analisis bahwa responden yang bekerja dengan masa kerja 30 tahun keatas tingkat kepuasan kerjanya rendah $30,6 \%$ dan tingkat kepuasan kerjanya tinggi $27,8 \%$ serta mayoritas responden memiliki tingkat kepuasan kerja sedang $41,7 \%$.

Tabel 9. Tabulasi Silang Antara Tingkat Kepuasan Kerja dengan Cara Mengekspresikan Tingkat Kepuasan Kerja Secara Konstruktif

\begin{tabular}{|c|c|c|c|c|c|}
\hline \multicolumn{3}{|c|}{$\begin{array}{l}\text { Aspirasi } \\
\text { Kesetiaan }\end{array}$} & Ekspresi & truktif & Total \\
\hline \multirow[t]{3}{*}{ Tingkat Kepuasan Kerja } & Rendah & $\begin{array}{l}\text { Count } \\
\% \text { of Total }\end{array}$ & $\begin{array}{r}11 \\
15.3 \% \\
\end{array}$ & $\begin{array}{r}11 \\
15.3 \% \\
\end{array}$ & $\begin{array}{r}22 \\
30.6 \% \\
\end{array}$ \\
\hline & Sedang & $\begin{array}{l}\text { Count } \\
\% \text { of Total }\end{array}$ & $\begin{array}{r}14 \\
19.4 \%\end{array}$ & $\begin{array}{r}16 \\
22.2 \% \\
\end{array}$ & $\begin{array}{r}30 \\
41.7 \% \\
\end{array}$ \\
\hline & Tinggi & $\begin{array}{l}\text { Count } \\
\% \text { of Total }\end{array}$ & $\begin{array}{r}13 \\
18.1 \% \\
\end{array}$ & $\begin{array}{r}7 \\
9.7 \% \\
\end{array}$ & $\begin{array}{r}20 \\
27.8 \% \\
\end{array}$ \\
\hline \multirow[t]{2}{*}{ Total } & & Count & 38 & 34 & 72 \\
\hline & $\%$ of Total & $52.8 \%$ & $47.2 \%$ & $100.0 \%$ & \\
\hline
\end{tabular}

Berdasarkan tabel 9 menunjukkan bahwa terdapat $11(15,3 \%)$ reponden memiliki tingkat kepuasankerjarendah dengan caramengekspresikan tingkat kepuasan kerja dalam bentuk aspirasi dan juga dalam bentuk kesetiaan. Dan terdapat 13 $(18,1 \%)$ responden memiliki tingkat kepuasan kerja tinggi dengan cara mengekspresikan tingkat kepuasan kerja dalam bentuk aspirasi sedangkan 7
$(9,7 \%)$ responden dalam bentuk kesetiaan.

Ini berarti responden yang memiliki tingkat kepuasan kerja rendah sebagian mengekspresikan tingkat kepuasan kerja dalam bentuk aspirasi dan sebagian dalam bentuk kesetiaan. Sedangkan responden yang memiliki tingkat kepuasan kerja tinggi cenderung mengekspresikan tingkat kepuasan kerja dalam bentuk aspirasi.

Tabel 10. Tabulasi Silang Antara Tingkat Kepuasan Kerja dengan Cara Mengekspresikan Tingkat Kepuasan Kerja

Secara Destruktif

\begin{tabular}{|c|c|c|c|c|c|}
\hline \multicolumn{3}{|c|}{$\begin{array}{c}\text { Keluar } \\
\text { Pengabaian }\end{array}$} & Ekspresi D & struktif & Total \\
\hline $\begin{array}{l}\text { Tingkat Kepuasan } \\
\text { Kerja }\end{array}$ & Rendah & $\begin{array}{l}\text { Count } \\
\% \text { of Total }\end{array}$ & $\begin{array}{r}16 \\
22.2 \% \\
\end{array}$ & $\begin{array}{r}6 \\
8.3 \% \\
\end{array}$ & $\begin{array}{r}22 \\
30.6 \% \\
\end{array}$ \\
\hline & Sedang & $\begin{array}{l}\text { Count } \\
\% \text { of Total }\end{array}$ & $\begin{array}{r}13 \\
18.1 \% \\
\end{array}$ & $\begin{array}{r}17 \\
23.6 \% \\
\end{array}$ & $\begin{array}{r}30 \\
41.7 \% \\
\end{array}$ \\
\hline & $\overline{\text { Tinggi }}$ & $\begin{array}{l}\text { Count } \\
\% \text { of Total }\end{array}$ & $\begin{array}{r}5 \\
6.9 \%\end{array}$ & $\begin{array}{r}15 \\
20.8 \% \\
\end{array}$ & $\begin{array}{r}20 \\
27.8 \% \\
\end{array}$ \\
\hline Total & & Count & 34 & 38 & 72 \\
\hline & $\%$ of Total & $47.2 \%$ & $52.8 \%$ & $100.0 \%$ & \\
\hline
\end{tabular}

Berdasarkan tabel 10 menunjukkan bahwa terdapat $16(22,2 \%)$ reponden memiliki tingkat kepuasankerjarendah dengan caramengekspresikan tingkat kepuasan kerja dalam bentuk keluar dan 6 $(8,3 \%)$ responden dalam bentuk pengabaian. Dan terdapat $5(6,9 \%)$ responden memiliki tingkat kepuasan kerja tinggi dengan cara mengekspresikan tingkat kepuasan kerja cenderung memilih keluar, sedangkan $15(20,8 \%)$ responden dalam bentuk pengabaian.

Ini berarti responden yang memiliki tingkat kepuasan kerja rendah cenderung mengekspresikan tingkat kepuasan kerja dengan memilih keluar yaitu dalam bentuk pindah ke unit kerja lain yang dianggap lebih sesuai dibanding dengan pengabaian yang dalam bentuk ketidakpedulian 
terhadap target perusahan. Sebaliknya responden yang memiliki tingkat kepuasan kerja tinggi cenderung mengekspresikan tingkat kepuasan kerja dalam bentuk pengabaian dibanding keluar atau meninggalkan organisasi. Hal ini sesuai dengan teori keadilan yang menyampaikan bahwa seseorang akan merasa puas atau tidak puas tergantung apakah ia merasakan keadilan atau tidak atas suatu situasi.

Tabel 11. Ekspresi Tingkat Kepuasan Kerja Tinggi Cenderung Destruktif

\begin{tabular}{|l|c|c|}
\hline $\begin{array}{c}\text { Ekspresi Tingkat } \\
\text { Kepuasan Kerja yang } \\
\text { Tinggi secara Destruktif }\end{array}$ & $\begin{array}{c}\text { Frekuensi } \\
\text { Subyek }\end{array}$ & $\%$ \\
\hline Keluar & 5 & 6,9 \\
Pengabaian & 15 & 20,8 \\
\hline \multicolumn{1}{|c|}{ Jumlah } & 20 & 100 \\
\hline
\end{tabular}

Tabel 12. Bentuk Perilaku dari Ekspresi Tingkat Kepuasan Kerja Tinggi Cenderung Destruktif

\begin{tabular}{|c|l|c|c|}
\hline No. & \multicolumn{1}{|c|}{ Pernyataan } & \multicolumn{2}{|c|}{ Persentase } \\
\cline { 3 - 4 } & & $4(\mathrm{~S})$ & $5(\mathrm{SS})$ \\
\hline 1. & $\begin{array}{l}\text { Saya bekerja sesuai } \\
\text { kemampuan saya tanpa } \\
\text { peduli target perusahan }\end{array}$ & 15 & 15 \\
\hline
\end{tabular}

Pada sebagian karyawan dengan masa kerja 30 tahun keatas yang kepuasan kerjanya rendah memiliki tingkat kepercayaan yang tinggi terhadap perusahaan. Karyawan percaya manajemen melakukan hal terbaik dalam membuat perubahan. Karyawan juga masih aktif memberikan aspirasi kepada pihak-pihak tertentu yang terkait dengan pekerjaan dan peningkatan kesejahteraan karyawan.

Dalam mengekspresikan kepuasan kerja, sebagian besar karyawan yang memiliki kepuasan rendah cenderung memilih pindah ke unit kerja lain yang dirasa lebih sesuai untuk dirinya. Sebagian karyawan juga cenderung mengabaikan, yaitu bekerja sesuai kemampuan tanpa peduli target perusahaan dan hal ini juga terdapat kecenderungan pada karyawan yang memiliki kepuasan kerja tinggi sebagaimana ditunjukkan pada tabel 10 dan 11. Nampaknya hal ini terdapat kecenderungan umum yang terjadi pada karyawan yang bermasa kerja 30 tahun keatas. Karyawan dengan berbagai alasan tidak melaksanakan pekerjaannya dengan baik bahkan karyawan tersebut merasa dirinya telah berbuat banyak untuk perusahaan sehingga telah tiba waktunya bekerja santai, datang dan 42 pulang tepat waktu serta seringkali mengatakan kepada karyawan yang lebih muda untuk bekerja lebih giat, bahkan tidak jarang pula meminta atau mengalihkan sebagian tanggung jawab yang seharusnya menjadi tanggung jawab karyawan tersebut.

Bekerja adalah salah satu cara manusia untuk memenuhi segala kebutuhan yang mereka inginkan. Namun, dalam bekerja seorang manusia tidak hanya memerlukan uang tetapi mereka juga menginginkan adanya peningkatan karir yang bisa menimbulkan kepuasan tersendiri pada diri manusia, sumbersumber kepuasan kerja memungkinkan timbulnya usaha-usaha peningkatan kebahagiaan hidup karyawan.

Berdasarkan angket terbuka dan hasil wawancara kepada 6 responden diketahui bahwasannya mereka yang memiliki kepuasan kerja rendah cenderung mencari kepuasan di bidang lain dengan cara aktif di kegiatan sosial baik di lingkungan kerja maupun di lingkungan rumah. Kegiatan sosial di lingkungan kerja misalnya aktif dalam kegiatan olah raga ataupun kesenian. Sedangkan kegiatan sosial di lingkungan rumah adalah kegiatan keagamaan.

Hasil penelitian pada variabel kepuasan kerja mendukung sintesis teori oleh Wexley dan Yuki, Blum, Gilmer, dan Harold E. Burt yang menyampaikan bahwa kepuasan kerja dipengaruhi oleh beberapa faktor yaitu kualitas pekerjaannya, lingkungan kerja, atasan, serta kebijakan perusahaan dalam hal pengelolaan SDM.

Pada variabel cara mengekspresikan kepuasan kerja yang rendah mendukung teori Robbins (2008) bahwa ekspresi kepuasan kerja yang rendah terletak pada dua dimensi yaitu konstruktif dan destruktif. Konstruktif didefinisikan dengan aspirasi (voice) dengan bentuk perilaku berdiskusi dengan pihak terkait untuk membuat suatu perubahan, kesetiaan (loyalty) dengan bentuk perilaku percaya terhadap manajemen dalam melakukan perubahan baik, sedangkan destruktif didefinisikan keluar (exit) dengan bentuk perilaku pindah ke unit kerja lain yang lebih sesuai, pengabaian (neglect) dengan bentuk perilaku bekerja sesuai kemampuan tanpa peduli target perusahaan.

\section{SIMPULAN}

Berdasarkan hasil analisis data penelitian, dapat diketahui bahwa :

1. Sebanyak 72 karyawan yang bekerja dengan 
masa kerja 30 tahun keatas memiliki tingkat kepuasan kerja sebagai berikut
a. Rendah
22 karyawan $(30,6 \%)$
b. Sedang
30 karyawan $(41,7 \%)$
c. Tinggi
20 karyawan $(27,8 \%)$

2. Faktor-faktor yang mempengaruhi tingkat kepuasan kerja karyawan

a. Faktor yang mendukung tingkat kepuasan kerja sebagian besar karyawan meliputi :

1. Tersedianya perlengkapan pegawai yang memadai

2. Kesejahteraan pegawai terjamin dengan adanya layanan kesehatan

3. Tersedianya sarana ibadah yang baik

b. Faktor yang kurang mendukung tingkat kepuasan kerja sebagian karyawan meliputi :

1. Hasil penilaian kinerja tidak ada umpan balik

2. Penerapan peraturan kurang tegas dan kurang adil

3. Belum adanya sistem karir (carrier planning) yang jelas.

3. Karyawan dengan masa kerja diatas 30 tahun dalam cara mengekspresikan kepuasan kerja yang rendah dengan dua cara yaitu konstruktif dan destruktif. Cenderung konstruktif mengekspresikan tingkat kepuasan kerja yang rendah dalam bentuk aspirasi dan sebagian kesetiaan. Sedangkan cenderung destruktif dengan keluar dan pengabaian. Bentuk perilaku cenderung konstruktif dan destruktif sebagai berikut :

a. Bentuk perilaku cenderung konstruktif

1. Berdiskusi dengan pihak terkait untuk membuat suatu perubahan

2. Percaya terhadap manajemen dalam melakukan perubahan baik

b. Bentuk perilaku cenderung destruktif

1. Pindah ke unit kerja lain yang lebih sesuai

2. Bekerja sesuai kemampuan tanpa peduli target perusahaan

\section{SARAN}

Dari hasil diatas dapat dirumuskan saran sebagai berikut:

1. Perusahaan dapat membuat suatu wadah atau menciptakan forum bagi karyawan yang telah bekerja lebih dari 30 tahun dengan memberikan kesempatan kepada karyawan untuk mensharingkan pengalaman atau membagi ilmunya selama bekerja di perusahaan, pengalaman kehidupan diri dan keluarganya, serta pengalaman atau rencana bisnisnya yang akan dilalui di masa pensiun.

2. Perusahaan hendaknya memberikan umpan balik terhadap penilaian kinerja karyawan dengan memberitahu penilaian kinerja secara transparan sebagai sarana evaluasi bagi karyawan untuk mendorong karyawan dalam meningkatkan kinerjanya.

3. Perusahaan diharapkan melakukan evaluasi jenjang karir dan mulai menerapkan sistem karir (carrier planning) yang jelas

\section{DAFTAR PUSTAKA}

As'ad, M. 2004. Psikologi Industri: Seri Ilmu Manajemen Sumber Daya Manusia. Yogyakarta: Liberty.

Gibson, Ivancevich \& Dannelly. 2002. Organisasi: Perilaku, Struktur, Proses Jilid I Terjemahan. Jakarta: Binarupa Aksara.

Handoko T.H. 1994. Manajemen Personalia dan Sumber Daya Manusia Edisi Keduabelas. Yogyakarta: BPFE.

Handoko, T.H. 2008. Manajemen Edisi Kedua. Yogyakarta: BPFE.

Hurlock, E.B. 1980. Psikologi Perkembangan Terjemahan Edisi Kelima. Jakarta: Airlangga.

Mathis, R.L. \& Jackson, J.H. 2006. Human Resource Management Terjemah Edisi Kesepuluh. Jakarta: Salemba Empat

Munandar, A.S. 2006. Psikologi Industri dan organisasi. Jakarta: UI Press.

Nazir, 2009. Metode Penelitian. Jakarta: Ghalia Indonesia.

Robbins, S.P. \& Judge T.A. 2008. Perilaku Organisasi Jilid I Terjemahan. Jakarta: Salemba Empat.

Siagian, S.P. 2007. Manajemen Sumber Daya Manusia. Jakarta: Bumi Aksara.

Simamora, H. 2004. Manajemen Sumber Daya Manusia. Yogyakarta: STIE-YKPN.

Wexley, K.N. \& Yuki, G.A. 2005. Perilaku Organisasi dan Psikologi Personalia Terjemahan. Jakarta: Rineka Cipta. 